\title{
Catastrophic glacial multi-phase mass movements: a special type of glacial hazard
}

\author{
D. A. Petrakov ${ }^{1}$, S. S. Chernomorets ${ }^{2}$, S. G. Evans ${ }^{3}$, and O. V. Tutubalina ${ }^{2}$ \\ ${ }^{1}$ Faculty of Geography, M.V. Lomonosov Moscow State University, Moscow, Russia \\ ${ }^{2}$ University Centre for Engineering Geodynamics and Monitoring, Moscow, Russia \\ ${ }^{3}$ Department of Earth and Environmental Sciences, University of Waterloo, Waterloo, Ontario, Canada
}

Received: 15 June 2007 - Revised: 25 March 2008 - Accepted: 31 March 2008 - Published: 10 April 2008

\begin{abstract}
Many glacier-related hazards are well typified and studied, but some events stand out from conventional classifications. The Kolka-Karmadon catastrophic event on 20 September 2002 in North Ossetia, North Caucasus, Russia is used as an example of a complex glacier failure exhibiting characteristics such as high mobility, long runout, ultrarapid movement and multiphase behaviour. We consider terminology protocol for glacier hazard classification and then, using the Kolka-Karmadon event and several other examples from around the world, we propose a new term for this family of events. Catastrophic glacier multi-phase mass movement (CGMM) is described and further illustrated by eight major events from Russia, Georgia, Peru, Chile, and Canada. CGMM have a combination of specific features: extraordinary velocities and long-distance runout despite low path angle; progressive fluidisation along travel path; superelevation and run-up of the moving mass, air blast wave in the avalanche flow phase; entrainment of available materials in its path, and the repeated nature of the event. CGMM events may affect areas remote from glaciers which were previously considered as safe.
\end{abstract}

\section{Introduction}

Glacial hazards are highly dangerous and hardly predictable natural hazards, characteristic for many mountain regions (Evans and Clague, 1994). They pose threat to population, infrastructure, human activities and economic development. The earliest known evidence of devastating glacial hazards in the Alps dates back to the medieval ages (Richard and Gay, 2003). In the Cordillera Blanca range, Peru, glacier hazards have killed more than 30000 people since 1702, when the town of Huaraz was inundated by a glacial flood. Increased

Correspondence to: D. A. Petrakov

(dpetrakov@gmail.com) use of alpine regions in recent decades intensifies the inherent conflict between glacial hazards and human activity. It is expected that the frequency, and in some cases the magnitude, of glacial hazards will increase due to global warming and consequent glacier retreat (Reynolds, 2003). As a result, glacial hazards may affect areas that were previously considered safe or have no historical record of this hazard.

Many glacier-related hazards such as lake outbursts (and consequent floods and debris flows), ice avalanches, glacier surges are well studied and typified. But some events stand out from conventional classifications (Kääb et al., 2005; Richardson and Reynolds, 2000; Reynolds, 2003) as exceptions or special cases. For example, the Kolka-Karmadon catastrophic event on 20 September 2002 in North Ossetia, North Caucasus, Russia has been described by various authors as a rock avalanche (Reynolds, 2003), a debris flow (Kotlyakov et al., 2004), and a glacier surge (Dessinov, 2004). Different attributions of this event show an absence of common opinion which could lead to mistakes in modelling and in evaluation of risk-prone zones. Such "unconventional" glacier hazards are rare but potentially devastating phenomena. Only a few such events have been documented in the mountain ranges of the world. Usually beginning as rock/ice avalanches, or slides, they transform into ultra-highspeed flows (more than $30 \mathrm{~m} / \mathrm{s}$ ) which may destroy areas at a distance of some tens of kilometers downstream from glacier limits. These flows often turn into a typical debris flow and then, in turn, into a debris flood which can travel many kilometers away from its source. Unpredictable and highly dangerous, these events may lead to numerous casualties and substantial destruction of downslope populated areas. Such phenomena call for special scientific attention and a specific research approach.

Published by Copernicus Publications on behalf of the European Geosciences Union. 
Our research is focussed on the analysis of these "unconventional" glacial hazards. We determine their distinctive features, attempt to explain these features and examine them in detail, using in particular the most recent and most studied case of the 2002 Kolka-Karmadon catastrophic event in Russia.

\section{Terminology}

As noted above, the Kolka-Karmadon catastrophic event has had no agreed definitive name to characterise the phenomenon. In fact, it was a complex type of hazard, which had features of both an ice/rock avalanche and a debris flow. The same naming problem also applies to the Huascaran disasters (Peru) in 1962 and 1970, where the terms "avalanche" and "debris flow" have both been used. In this paper, we try to select a suitable term to characterise these events in accordance with established terminology.

Glacier hazards are usually divided into mass movements, glacier floods and length/volume change (Reynolds, 2003; Kääb et al., 2005). Undoubtedly the studied phenomena fall into the class of glacier mass movements. Mass movement is usually defined as a rapid movement of debris, rocks or ice material from its source detachment area downslope. In the glacier environment mass movements include ice and rock avalanches, debris flows (Reynolds, 2003), rockslides and lahars (Kääb et al., 2005). Both the Kolka-Karmadon and Huascaran events were defined by some authors as rock avalanches, i.e., a high velocity transport of a fractured rock mass (Reynolds, 2003). What in fact was observed during these events was a high-velocity transport of fractured ice and rock mass, water and some surficial material (debris and snow) which transformed to an ultra-high speed flow due to fluidization. The Kolka-Karmadon event is difficult to assign to existing sediment-water flow or landslide classifications, and actually does not correspond to classical rock avalanches in various aspects (Huggel et al., 2005).

We propose to use a new term catastrophic glacier (glacial) multi-phase mass movement (CGMM) for this family of events. The most important stage of a CGMM is an ultra-high speed flow. This flow is an intermediate stage between an avalanche and a debris flow, and has features of both of these phenomena. So another term avalanche flow may be suitable to emphasise its specific parameters. Avalanche flow is an extremely high velocity transport of fractured ice/rock mass/surficial material, characterised by an air blast wave, a flow-like turbulent movement, superelevations and run-ups of the moving mass, a low path angle and long-distance runout.

Features of CGMM events and typical cases of avalanche flows are highlighted below in some examples.

\section{Case studies}

\subsection{Kolka-Karmadon catastrophic event}

The Kolka-Karmadon glacier disaster (20 September 2002, North Ossetia, Russia) is the largest documented CGMM in the world by volume of transported material. The origin of the event, its mechanism and consequences have been widely discussed (e.g., Haeberli et al., 2004; Huggel et al., 2005; Kääb et al., 2003; Kotlyakov et al., 2004; Petrakov et al., 2004; Popovnin et al., 2003; Tutubalina et al., 2005; Muraviev, 2004; Berger, 2007).

To analyse the origin of this event and characterise its features several methods were used. In 2001-2006 the authors organized twelve field trips to the disaster area. Field mapping and surveying, glaciological and geomorphological descriptions of the area were made. Beside the field research, we have analysed maps, previous studies of Kolka glacier and a large number of remotely-sensed images (taken from helicopters, by Landsat ETM+, Terra ASTER, IRS LISS/Pan QuickBird satellite sensors, and by a digital camera onboard the International Space Station). Seismic records as well as eye-witness accounts were used for velocity calculations and the assessment of pre-catastrophe conditions.

This catastrophe was triggered, with a time lag, by a series of ice-rock falls/collapses from northern face of Mt. Dzhimarai-khokh onto the rear part of Kolka Glacier. The collapses started two months before the event took place, and their total volume was about $18 \mathrm{M} \mathrm{m}^{3}$ (most of this fell before 20 September 2000). Some rockfalls continued after the event. We hypothesise that tension in the glacier body increased due to surface overload. A satellite image taken 8.5 hours before the disaster shows instability within the glacier body: in the upper part of the Kolka snout, some ice displacement was observed, but glacier terminus was still stationary (Tutubalina et al., 2005). The main part $\left(80 \mathrm{M} \mathrm{m}^{3}\right)$ of Kolka glacier detached (Fig. 1a) and travelled up to $19 \mathrm{~km}$ downstream with an extraordinary average velocity of $50 \mathrm{~m} / \mathrm{s}$ (Drobyshev, 2006; Huggel et al., 2005; Petrakov et al., 2004).

It is hard to define how exactly the start of the glacier detachment occurred. Reduction of friction at the base of the glacier body and the reduction in the mass strength of the glacier due to increase of tension and displacement of ice layers may have led to sliding. Some authors hypothesize that the trigger was an under-glacier volcanic gas explosion (Muraviev, 2004) or that the event was a culmination of a fast gas-induced glacier movement (Berger, 2007). What we can conclude with certainty is that just before the event the glacier was unstable and apparently ready for catastrophic movement.

In its first stage the movement was of a slide-type with relatively small water content. The ice/rock mass polished the moraine surfaces down the valley and created boulder pavements. Rocks on the moraine slopes were covered by striations up to $3 \mathrm{~mm}$ deep, and the directions of these recorded 



Fig. 1. (A) Kolka glacier cirque after the disaster (photo by A. P. Polkvoi). 1 - origination area of initial collapses, 2 - former Kolka glacier, 3 - areas with striations, 4 - Maili glacier snout. (B) striations on moraine deposits (photo by D. A. Petrakov).

the direction of the flow (Fig. 1a and b) typical for glacier erosion. A few kilometers downstream the striations disappear, and we conclude that the ice mass fluidized due to complete disintegration and basal melting.

During the second and main stage of the movement, the ice/water/rock mass moved from one valley side to the other within a belt $400-500 \mathrm{~m}$ wide. The moving mass left asymmetric superelevations up to $250 \mathrm{~m}$ in height (Fig. 2a). A
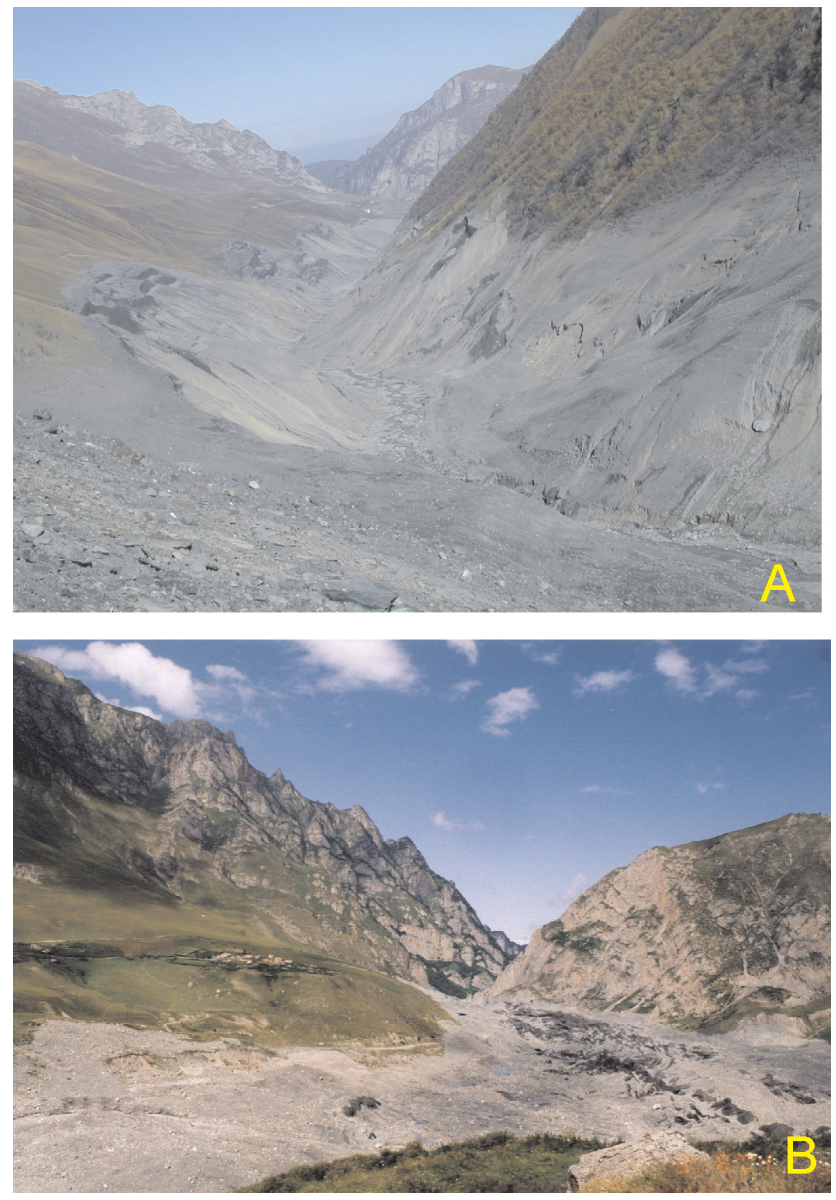

Fig. 2. (A) travel path of the Kolka-Karmadon glacier avalanche flow (photo by I. V. Galushkin). (B) Karmadon depression filled by debris-covered ice, two years after the disaster (photo by S. S. Chernomorets).

layer of wind-borne debris, $10-20 \mathrm{~m}$ wide and $3-10 \mathrm{~cm}$ thick, was deposited on vegetated slopes above the superelevations. Debris under $10 \mathrm{~cm}$ in size were prevalent with single pieces reaching $30-40 \mathrm{~cm}$. On the right side of the valley trees were felled by the air blast wave and also covered by wind-borne dust and debris. According to calculations of Drobyshev (2006), based on geodetic measurements of superelevation geometry, the maximum velocity of the flow reached $70 \mathrm{~m} / \mathrm{s}$, the average was about $50 \mathrm{~m} / \mathrm{s}$, while Huggel et al. (2005) reported average velocity as $90 \mathrm{~m} / \mathrm{s}$.

$120 \mathrm{M} \mathrm{m}^{3}$ of ice and debris were transported to the Karmadon depression $19 \mathrm{~km}$ downstream from the source. A narrow gorge of the Skalistyi Range (Fig. 2b) stopped most of the mass movement. Bodies of birds were found smashed into the steep south face of the mountain range immediately after the disaster, indicating an air blast wave. Run-up of about $20 \mathrm{~m}$ high (above the surface of the moving mass) was also observed at the same place, so the halt of the flow was sudden and forced. 
Table 1. Typical cases of multi-phased glacial hazards (Casassa and Marangunic, 1993; Evans, 2004; Evans et al., 1989; Evans et al., 2007; Mokievsky-Zubok, 1978; Morales, 1966; Plafker and Ericksen, 1978; Popovnin et al., 2003; Statkowsky, 1877; Stoeber, 1903).

\begin{tabular}{|c|c|c|c|c|c|c|c|c|c|}
\hline Event & Phases & Year & $\begin{array}{l}\text { Volume estimate, } \\
\mathrm{M} \mathrm{m}^{3}\end{array}$ & $\begin{array}{l}\text { Height of } \\
\text { path } \mathrm{H}, \mathrm{km}\end{array}$ & $\begin{array}{l}\text { Length of } \\
\text { path L, km }\end{array}$ & $\mathrm{H} / \mathrm{L}$ & $\begin{array}{l}\text { Path angle, } \\
\text { degrees }\end{array}$ & Deaths & $\begin{array}{l}\text { Velocity, } \\
\mathrm{m} / \mathrm{s}\end{array}$ \\
\hline Devastation & GS-AF-DF & 1975 & $13-30$ & 1.22 & 7 & 0.17 & 10 & 4 & 30 \\
\hline Huascaran & IRA-AF-DF & 1962 & 13 & 3.60 & 15.52 & 0.23 & 13 & 4000 & 50 \\
\hline Huascaran & IRA-AF-DF & 1970 & 60 & $\begin{array}{l}3.85 \\
6 \\
\text { (total) }\end{array}$ & $\begin{array}{l}15.6 \\
175 \\
\text { (total) }\end{array}$ & 0.25 & 14 & 18000 & 97 \\
\hline Kolka-Karmadon & IRA-GS-AF-DF & 2002 & 140 & $\begin{array}{l}2 \\
2.5 \\
\text { (total) }\end{array}$ & $\begin{array}{l}19 \\
36 \\
\text { (total) }\end{array}$ & $\begin{array}{l}0.11 \\
0.07\end{array}$ & 64 & 125 & 50 \\
\hline Pandemonium & RA-DF & 1959 & 7 & 2 & 8.6 & 0.23 & 13 & & 100 (max.) \\
\hline Parraguirre & RS-DF & 1987 & 15 & 3.4 & 57 & 0.06 & 3.5 & 37 & 19 \\
\hline
\end{tabular}

Abbreviations: AF - avalanche flow, DF - debris flow, GS - glacier slide, IRA - ice-rock avalanche, RA - rock avalanche, RS - rockslide.

Despite a low travel path angle $\left(6^{\circ}\right)$ the ice/debris/water mass had enough energy for further movement. As a result, during the third movement stage, a distal debris flow travelled for an additional $17 \mathrm{~km}$ downstream. The total area directly affected by the disaster was $12.7 \mathrm{~km}^{2}$, and at least 125 people perished.

Similar catastrophes have been observed in the Genaldon River valley prior to 2002. In 1902 the CGMM from Kolka glacier stopped $6 \mathrm{~km}$ upstream of the Skalistyi Range (Stoeber, 1903). There is also some evidence of similar pre-1902 events, recorded both in local legends and surficial deposits in the valley.

The 2002 Kolka-Karmadon event had many distinctive features. Briefly, they are as follows; 1) multi-phase movement with transformation from a glacier slide to a debris flow; 2) extremely high velocities and long runout despite a low travel path angle, 3) fluidization and superelevation of the moving mass along the travel path, 4) a dramatic air blast wave, and 5) a complete detachment of the main part of the glacier from its bed. Therefore, this event cannot be defined as either an avalanche or a debris flow but has features of both. We define it as a CGMM event in which the main stage flow during the mass movement may be termed an avalanche flow.

\subsection{Other events}

We analyzed a number of previously documented glacial hazard events with similar features to the Kolka-Karmadon and which we consider to be CGMM events. Summary statistics of these events, together with the 1902 and 2002 KolkaKarmadon events are presented in Table 1. Below we give a brief characterisation of the six additional events.
3.2.1 Devastation Glacier slide (British Columbia, Canada, 22 July 1975)

This event resulted from the displacement of volcanic rocks below the glacier bed, and a part of the glacier snout with volume about $2.5 \mathrm{M} \mathrm{m}^{3}$ moved downstream. During travel the slide transformed into a debris flow highly saturated with water and ice. Due to entrainment its volume grew significantly, and superelevations reached $100 \mathrm{~m}$. No volcanic or seismic activities were recorded on that day, so the slide was triggered mainly due to the action of glacier melt water (Evans, 2004; Mokievsky-Zubok, 1978).

\subsubsection{Devdorak Glacier (Caucasus, Georgia and Russia)}

The surging-type Devdorak Glacier was probably the most famous glacier of the Russian Empire in the 19th century. The well known "Kazbek blockages" stopped transportation between Russia and Georgia, which at the time had just joined the Russian Empire. In 1832, for example, the Terek River was blocked for $8 \mathrm{~h}$, the ice blockage was up to $100 \mathrm{~m}$ in height. "Kazbek blockages" were triggered by the advance of the Devdorak glacier along a narrow gorge (Statkowsky, 1877). The valley of the Amilishka River, which flows from the Devdorak glacier, was blocked by glacier ice. After this, on a number of occasions, hydrodynamic impact led to glacier snout detachment, its slide down valley and transformation to an avalanche flow due to fluidisation. Not all of these glacier surges resulted in a blockage, e.g. this did not happen during surges in 1843, 1855 (Statkowsky, 1877). 


\subsubsection{2 and 1970 Huascaran events (Cordillera Blanca, Peru)}

The catastrophic glacial events of 1962 and especially of 1970 in the Cordillera Blanca of Peru were the worst glacier disasters of the twentieth century. The towns of Ranrahirca and Yungay were buried by thick layers of mud and debris in 1962 and 1970 respectively. A total of 25000 people were killed. In 1962, as well as in 1970, the event started as an ice-rock avalanche (IRA) from the western face of the north summit of Mt. Huascaran (6654 m a.s.l.). In 1970 the disaster was triggered by a M7.9 earthquake, while the nature of the trigger in 1962 is not clear. Below the steep wall $\left(65^{\circ}\right)$ the ice-rock avalanche fell onto Glacier 511. The avalanche travelled down with accelerating velocity due to low friction, its material pulverized and fluidised. Below the glacier the avalanche transformed into an avalanche flow and entrained moraine debris into a catastrophic mass movement (Evans et al., 2007) (Fig. 3). Velocities of the avalanche flow were extremely high. Run-ups and superelevations were observed. As a result, in 1970 part of the flow jumped over the Cerro del Aira ridge ( $230 \mathrm{~m}$ height) and overwhelmed the town of Yungay. In Huashao settlement, a unique phenomenon of stone hailstorm was observed. Some rocks were over 1 tonne in weight, 50 people were killed. Blocks of rock flew for up to $4 \mathrm{~km}$, and so their velocity in the starting point should be no less then $850 \mathrm{~km} / \mathrm{h}$ (Stadelmann, 1983). A typical air blast wave was observed before the village of Matacoto, where trees were thrown down and a $40 \mathrm{~m}$ run-up was registered (Plafker and Ericksen, 1978). A distal debris flow along Río Santa travelled all the way to Pacific Ocean (Evans et al., 2007).

\subsubsection{Pandemonium Creek rock avalanche (Coast Mountains, British Columbia, Canada)}

The 1959 Pandemonium Creek event was one of fastest events documented. Its extremely high velocity may be a result of travelling over glacier surface (Evans et al., 1989). A rock avalanche $4-6 \mathrm{M} \mathrm{m}^{3}$ in volume collapsed onto a glacier and travelled down valley to the main channel of the Pandemonium Creek. The run-up in Pandemonium Creek valley reached $335 \mathrm{~m}$, and superelevations reached up to $70 \mathrm{~m}$ high further downstream as the mass transformed into a debris flow. It reached velocities of $80-100 \mathrm{~m} / \mathrm{s}$ just before the run-up, and these fell to $20-40 \mathrm{~m} / \mathrm{s}$ on exiting the Pandemonium Creek valley.

\subsubsection{Parraguirre event (Andes, Chile)}

The Parraguirre event began as a rockslide with a volume of $6 \mathrm{M} \mathrm{m}^{3}$ and the process quickly transformed into a rock avalanche (Casassa and Marangunic, 1993; Hauser, 2002). Within $5 \mathrm{~km}$ from its source the avalanche developed into a great debris flow due to incorporation of glacier ice and



Fig. 3. Huascaran glacier disaster of 31 May 1970: typical case of a glacial multi-phase mass movement. Photo by W. Welsch (from Patzelt, 1983).

segregated ice near the source area, and snow along the travel path. The debris flow claimed at least 37 lives during its rapid movement down the Río Colorado. Flow frontal waves were $20-30 \mathrm{~m}$ high. The exceptionally abundant snowfalls during the winter of 1987 and a high November snowmelt rate were listed as possible triggers, as well as progressive failure due to an earthquake in 1985 as a possible secondary factor (Casassa and Marangunic, 1993; Hauser, 2002).

In summary, each of the described events has unique features, but all of them are multi-phase movements resulting from a series of transformations in movement mode during travel. Extremely high velocities and long distance runout are typically manifested through avalanche flow character of mass movements.

\section{Discussion}

\subsection{Stages of multi-phase mass movements}

We have tried to determine the main phases of CGMM events. Results are presented in Table 1 and in Fig. 4. Different colors in Fig. 4 signify different events.

The initiation mechanisms of CGMM events may be very different. Usually the initial failure begins as an avalanche or a slide (Fig. 4). Their causes vary, but undoubtedly require a poor mechanical stability of rocks or ice. A seismic trigger may act immediately (e.g., Huascaran in 1970) as well as, possibly, with delay of months (Kolka-Karmadon in 2002) or years (Parraguirre in 1987). Melt or rain water, and snow overload, as well as permafrost melt or hanging glaciers shrinkage may further amplify slope instability.

For preparation of the main body displacement (a first main stage of a CGMM) a combination of factors is usually necessary. Initial failure may be the first step of the 




Fig. 4. Main stages of catastrophic glacial multi-phase mass movements (CGMM).

Abbreviations: AF - avalanche flow, DF - debris flow, GS - glacier slide, IRA - ice-rock avalanche, RA - rock avalanche, RS - rockslide. Coloured arrows correspond to events: red - Devdorak, rose - Devastation, blue - Kolka-Karmadon, yellow - Huascaran, grey - Pandemonium, dark blue - Parraguirre. Photos on the left: (A) glacier slide (Devastation Glacier), (B) avalanche flow (Kolka-Karmadon, photo by D. A. Petrakov), (C) debris flow (Kolka-Karmadon, photo by S. S. Chernomorets).

immediate main body displacement as it was in the Devastation Glacier case, or may act just as destabilising factor, e.g. ice and rock avalanches on Kolka Glacier in 2002 two months before the event. We suggest that the main mass has to be in the state of "preparedness" for catastrophic movement before the final trigger. Preparation may continue for many years and include accumulation of potential moving mass and/or disagregation of rocks and glacier ice, as well as formation of rupture planes. Without preliminary preparation even the impact of a high magnitude earthquake may not lead to a mass movement.

In the majority of cases we have studied, an avalanche or a slide quickly transforms into an avalanche flow (AF). Absence of this stage in the Pandemonium and Parraguirre events may be explained by a negligible content of glacier ice in the moving mass. For the development of an avalanche flow, a complete fracturing and fluidisation of moving mass is necessary. Due to fracturing, the ice mass disaggregates and the movement type transforms from laminar to turbulent. Snow and ice contained in the flow melts, leading to a decrease of flow strength and thus an increase in runout distance. However, water content in an avalanche flow may vary significantly. This phenomena was noted in the Parraguirre event where a "dry flow" travelled for a few kilometers. Water content in the flow was not enough for a fully-fluidised movement (Casassa and Marangunic, 1993). Most likely, the same phenomena occurred during the Kolka-Karmadon event. Fluidisation allows avalanche flows to travel over low path angles. Normally for ice avalanches the path angle should be over $17^{\circ}$ (Alean, 1985; Huggel et al., 2004). Sometimes the angle may be slightly less (Huggel and CaplanAuerbach, 2007) but without fluidisation the runout distance is restricted. Whether fluidisation will occur or not during an event is very difficult to predict: this may depend on such factors as the volume of ice involved in the mass movement, the total volume of the moving mass, the influence of topography, and the availability of wet entrainable material or snow in the path.

Avalanche flow may lead to drastic entrainment of path deposits. Entrainment depends on the forces acting on the available deposits which are defined mostly by the path angle, flow velocities and the flow density. If the flow density is low (such as in the Kolka-Karmadon event) the flow volume may increase by some tens of percent, but if the flow density is high (such as the Huascaran events) the flow volume may increase by as much as an order of magnitude. 
The last stage of a CGMM event is typically a debris flow (Fig. 4). Fluidisation due to the ice/snow melt increases water content of the flow. Avalanche/avalanche flow may transform to a debris flow entirely or just produce a distal debris flow immediately after the main mass stops. Distal debris flows may impact areas tens of kilometres downstream. This situation was observed in all studied events. Damming of rivers, and formation of debris-dammed lakes may lead to outburst floods and debris flows following a CGMM.

\subsection{Features of multi-phase mass movements}

All of the glacial mass movements noted above were complex events with rapid transformation of an initial failure mass into a devastating avalanche flow. All these mass movements originated from glaciers or near-glacier environments as avalanches or slides and finished their movements as flows. The main feature of a multi-phase mass movement (CGMM) is transformation of the movement mechanism. This transformation is mainly a result of some type of fluidisation. The main stage of a multi-phase mass movement is an avalanche flow. Avalanche flow has several distinctive features combining elements of both avalanches and debris flows:

1. Extremely high velocities, (up to $100 \mathrm{~m} / \mathrm{s}$ and more), despite the low travel angle, are much higher than debris flow velocities and comparable with avalanches;

2. A direct consequence of extraordinary velocities is an air blast wave - a typical avalanche feature observed during most avalanche flows. For example, during the 1902 Kolka-Karmadon event a woman standing at a distance of $200 \mathrm{~m}$ from the path was blown away and injured. Earlier, in the same region, according to oral history, the settlement of Genal was destroyed by a similar air blast wave. An air blast wave was also observed during the 1962 (Morales, 1966) and 1970 (Plafker and Ericksen, 1978; Stadelmann, 1983) Huascaran events;

3. Superelevations and run-ups of the mass along its travel path are results of extraordinary velocities and turbulent flow-type movement;

4. CGMM events have low travel path angles and as a result a long-distance runout. Their path angle is much lower than the path angle of avalanches and is comparable to path angles of debris flows. Sometimes the path angle of a CGMM event is lower then the typical path angle for debris flows $\left(11^{\circ}\right.$ according to Haeberli (1983)) and comparable to the path angle of a debris flood;

5. Entrainment observed during CGMM is more similar to debris flows than to avalanches. The entrainment ratio may be up to 10 .
Catastrophic glacial multi-phase mass movements as a whole have other important features. They repeat from time to time in the same area, but no clear return periods have been identified. This characteristic is very important for hazard assessment. Catastrophic events from Devastation Glacier were registered three times in the 20th century (Evans, 2004), at Kolka Glacier events occurred in 2002, 1902 and earlier, at Huascaran events in 1962, 1970 were preceded by a pre-Colombian event (Plafker and Ericksen, 1978). Kazbek blockages from Devdorak were registered six times, and ancient CGMM deposits were found in the Parraguirre event area (Casassa and Marangunic, 1993). Volume, distance and velocity of CGMM events may differ within at least one order of magnitude.

CGMM events usually have a complex trigger mechanism. Glacier ice and snow play an important role in the formation of CGMM events. Incorporated in mass movement they decrease flow resistance of the debris, melt and decrease friction due to fluidisation. The slide of debris over glacier surfaces leads to friction decrease and an increase in velocity and travel distance (Evans and Clague, 1988). In the final part of their travel path CGMM events may form temporary debris/ice dams which are usually very unstable.

\section{Conclusions}

The catastrophic events examined in this paper were multiphase mass movements originating from glaciers or nearglacier environments. All these movements are complex events involving transformation of movement type from icerock avalanche or glacier slide, to avalanche flow and finally to debris flow due to fluidisation. Hazard evaluation for these types of mass movements is extremely difficult because of their special features in contrast to avalanches and debris flows. These features are as follows: extraordinary velocities and long-distance runout despite low path angle; progressive fluidisation along travel path; superelevation and run-up of the moving mass, air blast wave in the avalanche flow phase; incorporation (entrainment) of available materials in its path (which may include snow), and the repeated nature of the event. CGMM events may affect areas remote from glaciers which were previously considered as safe. Careful evaluation of this rare phenomena, especially of its main stage (avalanche flow) is needed in order to prevent loss of life and destruction in populated areas.

Acknowledgements. The study was funded by: the NATO Science for Peace and Security Programme, project 982143; by the Russian Foundation for Basic Research, projects 06-05-64787 and 07-0500172; the Russian Programme of Leading Science Schools Support, grants 500.2008.5 and 8306.2006.5. We thank the Organising Committee of the 2nd Alexander von Humboldt Conference, especially P. Fabian, P. Lagos, G. Chia and J. L. Chau for excellent organisation and partial travel support. We also thank V. Drobyshev, A. Bozhinskiy and our reviewers for valuable comments, discussion and critical evaluation. 
Edited by: P. Fabian

Reviewed by: C. Huggel, M. Larsen, R. Guthrie, and O. Korup

\section{References}

Alean, J.: Ice avalanches: some empirical information about their formation and reach, J. Glaciol., 31(109), 324-333, 1985.

Berger, M. G.: Three glacio-dynamical surges and four gasdynamical outbursts of the Kolka Glacier: little-known pages and difficult questions of development of a surging glacier history, KomKniga, Moscow, 2007 (in Russian).

Caplan-Auerbach, J. and Huggel, C.: Precursory seismicity associated with frequent, large ice avalanches on Iliamna volcano, Alaska, USA, J. Glaciol., 53(180), 128-140, 2007.

Cassassa, G. and Marangunic, C.: The 1987 Río Colorado rockslide and debris flow, Central Andes, Chile, Bulletin of the Association of Engineering Geologists, XXX, 321-330, 1993.

Dessinov, L. V.: Surge of the Kolka glacier in 2002, Bulletin of Vladikavkaz Scientific Centre, 4(3), 72-87, 2004 (in Russian).

Drobyshev, V. N.: Glacial catastrophe of 20 September 2002 in North Osetia. Russ. J. Earth Sci., 8, ES4004, doi:10.2205/2006ES000207, 2006.

Evans, S. G.: The 1975 Devastation Glacier rockslide-debris avalanche, Mount Meager volcanic complex, southwestern British Columbia, Canada, Geophys. Res. Abstr., 6, 05903, 2004.

Evans, S. G. and Clague, J. J.: Catastrophic rock avalanches in glacial environments, Proceedings, 5th International Symposium on Landslides, Lausanne, Switzerland, 2, 1153-1158, 1988.

Evans, S. G. and Clague, J. J.: Recent climatic change and catastrophic geomorphic processes in mountain environments, Geomorphology, 10, 107-128, 1994.

Evans, S. G., Clague, J. J., Woodsworth, G. J., and Hungr, O.: The Pandemonium Creek rock avalanche, British Columbia, Can. Geotech. J., 26, 427-446, 1989.

Evans, S. G., Fidel Smoll, L., Zegarra Loo, J.: Los movimientos en masa de 1962 y 1970 en el Nevado de Huascarán, valle del rio Santa, Cordillera Blanca, Perú, Anexo B4, in: Movimientos en Masa en la Región Andina: Una guía para la evaluación de amenazas Proyecto Multinacional Andino: Geociencias para las Comunidades Andinas, Publicacion Geologica Multinacional, 4, 386-404, 2007.

Haeberli, W.: Frequency and characteristics of glacier floods in the Swiss Alps, Ann. Glaciol., 4, 85-90, 1983.

Haeberli, W., Huggel, C., Kaab, A., Oswald, S., Polkvoj, A., Zotikov I., and Osokin, N.: The Kolka-Karmadon rock/ice slide of 20 September 2002 - an extraordinary event of historical dimensions in North Ossetia (Russian Caucasus), J. Glaciol., 50, 533-546, 2004.

Hauser, A.: Rock avalanche and resulting debris flow in Estero Parraguirre and Rio Colorado, Region Metropolitana, Chile, Geol. Soc. Am., XV, 135-148, 2002.

Huggel, C., Haeberli, W., Kääb, A., Bieri D., and Richardson S.: Assessment procedures for glacial hazards in the Swiss Alps, Can. Geotech. J., 41(6), 1068-1083, 2004.

Huggel, C., Zgraggen-Oswald, S., Haeberli, W., Kääb, A., Polkvoj, A., Galushkin, I., and Evans, S. G.: The 2002 rock/ice avalanche at Kolka/Karmadon, Russian Caucasus: assessment of extraordinary avalanche formation and mobility, and application of QuickBird satellite imagery, Nat. Hazards Earth Syst. Sci., 5, 173-187, 2005, http://www.nat-hazards-earth-syst-sci.net/5/173/2005/.
Kääb, A., Wessels, R., Haeberli, W., Huggel, C., Kargel, J. S., and Khalsa, S. J. S.: Rapid ASTER imaging facilitates timely assessment of glacier hazards and disasters, Eos, Transactions, American Geophysical Union, 84(13), 117-121, 2003.

Kääb, A., Huggel, C., Fischer, L., Guex, S., Paul, F., Roer, I., Salzmann, N., Schlaefli, S., Schmutz, K., Schneider, D., Strozzi, T., and Weidmann, Y.: Remote sensing of glacier- and permafrostrelated hazards in high mountains: an overview, Nat. Hazards Earth Syst. Sci., 5, 527-554, 2005, http://www.nat-hazards-earth-syst-sci.net/5/527/2005/.

Kotlyakov, V. M., Rototaeva, O. V., and Nosenko, G. A.: The September 2002 Kolka Glacier Catastrophe in North Ossetia, Russian Federation: evidence and analysis, Mountain Res. Develop., 24, 78-83, 2004.

Mokievsky-Zubok, O.: A slide of glacier ice and rocks in West-ern Canada. J. Glaciol., 20(82), 215-217, 1978.

Morales B.: The Huascaran avalanche in the Santa Valley, Peru, IASH Publication, 69, 304-315, 1966.

Muravyev, Ya. D.: Subglacial Geothermal Eruption - the Possible Reason of Catastrophic Surge of Kolka Glacier in Kazbek Volcanic Massif (Caucasus), Bulletin of Kamchatka Regional Association "Educational-Scientific Center". Earth Sci., 4, 6-20, 2004.

Patzelt, G. (Ed.): Die Berg - und Gletschersturze vom Huascaran, Cordillera Blanca, Peru, Hochgebirgsforschung Heft 6, Universitatsverlag Wagner, Innsbruck, 51-70, 1983.

Petrakov, D. A., Tutubalina, O. V., and Chernomorets, S. S.: The 2002 Genaldon glacial catastrophe: one year later, Kriosfera Zemli, VIII(1), 29-39, 2004 (in Russian).

Plafker, G. and Ericksen G. E.: Nevados Huascaran avalanches, Peru, in: Rockslides and Avalanches, Vol. 1, Natural Phenomenon, edited by: Voight, B., Elsevier, 277-314, 1978.

Popovnin, V. V., Petrakov, D. A., Tutubalina, O. V., and Chernomorets, S. S.: The 2002 glacial catastrophe in North Ossetia, Kriosfera Zemli, VII(1), 3-17, 2003 (in Russian).

Reynolds, J. M. (Ed.): Development of glacial hazard and risk minimization protocol in rural environment, Report No R7816, Reynolds Geo-Sciences LTD, UK, 36 pp., 2003.

Richard, D. and Gay, M. (Eds.): GLACIORISK. Survey and prevention of extreme glaciological hazards in European mountainous regions, EVG1 200000512 Final report (01.01.2001-31.12.2003), 58 pp., http://glaciorisk.grenoble. cemagref.fr, 2003.

Richardson, S. D. and Reynolds, J. M.: An overview of glacial hazards in the Himalayas, Quaternary Int., 65(66), 31-47, 2000.

Statkowsky, B. I.: Origin of Kazbek ice blockage and measures for its prevention, Tiflis, 42 pp., 1877 (in Russian).

Stoeber, E. A.: Glacier collapses in the headwaters of the Genaldon River in the Caucasus, Terskiy sbornik, 2(7), 72-81, 1903 (in Russian).

Tutubalina, O. V., Chernomorets, S. S., and Petrakov D. A.: Kolka Glacier before the 2002 collapse: new data, Kriosfera Zemli, IX(4), 62-71, 2005 (in Russian).

von Stadelmann, J.: Zur Dokumentation der Bergsturzereignisse vom Huascaran, in: Die Berg - und Gletschersturze vom Huascaran, Cordillera Blanca, Peru, edited by Patzelt, G. Hochgebirgsforschung Heft 6, Universitatsverlag Wagner, Innsbruck, 51-70, 1983 